\title{
Solid Wastes Produced in a Turkish State Hospital Kitchen
}

Aysun Yuksel ${ }^{1^{*}}$ and Aydan Ercan ${ }^{2}$

${ }^{1}$ Department of Nutrition and Dietetics, Faculty of Health Sciences, Cumhuriyet University, Sivas, Turkey

${ }^{2}$ Department of Nutrition and Dietetics, Faculty of Health Sciences Baskent University, Ankara, Turkey

*Corresponding author: Yuksel A, Faculty of Health Sciences, Department of Nutrition and Dietetics, Cumhuriyet University, Sivas, Turkey, Tel: +90 3462191239 ; Fax: +90 34621911 10; E-mail: dyt.aysun@hotmail.com

Received date: Mar 07, 2017; Accepted date: Mar 23, 2017; Published date: Apr 01, 2017

Copyright: (C) 2017 Yuksel A, et al. This is an open-access article distributed under the terms of the Creative Commons Attribution License, which permits unrestricted use, distribution, and reproduction in any medium, provided the original author and source are credited.

\section{Abstract}

Waste is defined as a disposed material that is unwanted in some place or that has no value in the eyes of its producer. It is generated amply in industry, transportation, agriculture, tourism, food sector etc., in the process of production or service. These materials are distinguished from the concept "garbage" due to their economic and environmental value. It is necessary to decrease wastage at its source, and to re-gain and re-use or dispose the inevitable wastage in the manner least harmful to the environment.

Keywords: Solid waste; Environment; Garbage; Consumption

\section{Introduction}

Solid wastage is generally classified according to its qualities and these are $[1,2]$

- Organic wastage (fruits, vegetables, food waste etc. that nature can dissolve on its own)

- Recyclable wastage (plastic, glass, paper, metal, aluminum etc.)

- Medical wastage (all waste that has been in contact with the patient, injector, blood bag, etc.)

- Agricultural wastage (pesticide residue etc.)

- Dangerous wastage (self-inflammatory wastes, wastes that exhales flammable gases in the case of contact with water, poisonous and toxic wastes)

- Special quality wastage (radioactive wastes, batteries, power supplies, oils and excavation wastes which profess special importance in terms of their removal) [3-6].

\section{Food Wastage}

The increased world population, parallel to the increased demands; derogation of the physical conditions of the world and waning of natural resources has brought the problem of incapacity in satisfying the needs of nutrition [7]. Food and Agriculture Organization of the United Nations (FAO) reports that it is necessary to increase agricultural production by $60 \%$ until 2050 in order to satisfy the increased population's food demand [8]. Studies on "sustainable agriculture and food" has gained pace in order to safely sustain the nutrition demand of the growing population and in order to leave the following generations a livable planet $[9,10]$. On the other hand, the relation with environment, that is to say the negative pressure of global warming on natural resources caused by pollution is seen as the most important problem that jeopardizes agriculture and food sustainability [8]. Environment is the primary step and the most important resource in sustaining mankind's basic need of nutrition [11]. Food industry is a branch of industry which takes its raw materials from agriculture industry and transforms the agricultural produce into food through a series of processes. Hence food production and agricultural production are directly related: Environment is essential for food production.

In the production of any food both basic natural resources such as soil and water; and energy-in terms of preserving its freshness is utilized. Considering the abundance of energy world requires, it is an obligation to consume the produced food as efficiently as possible and it is important and imperative to re-use the waste produced after this efficient consumption [12]. A research indicates that $64 \%$ of the waste produced in the catering industry is avoidable and $18 \%$ may be avoidable whereas only $18 \%$ is unavoidable.

As in all branches of the industry, in the food industry as well, production of packaged goods has gained pace, as well as the generation of packaging waste due to their consumption. According to European Union package and packaging waste directives; packaging waste is defined as "the totality of the material both recyclable and unrecyclable used to deliver, protect, preserve and put on the market any good from the stage of raw material to the consumption good and from the delivery of that good from the producer to the consumer or utilizer" and package is the material which preserves the product so that it is delivered to the consumer in a healthy state; which introduces and effects the selling of the product [13]. Shampoo bottles, fruit juice cartoons and bottles, oil cans are examples of packaging waste produced in households. Being produced with different materials, these packaging wastes have an effect on the environment and pollution.

In all the world, within the approach of sustainable development, management strategies of transforming wastage which professes threat to human and environmental health into an economic input are developed $[2,4,14]$. In terms of the wastes that can be utilized as secondary raw materials, from their production to disposal, responsibility and due diligence resides both at the producer and the consumer [15].

Waste management approaches are linked to the sustainable usage of resources. It is a humanitarian duty for individuals to consider the following generations in their necessary consumption of finite natural resources. Recycling gradable wastage is beneficial both for the economy and the environment. Materials such as plastic, glass, metal, 
paper, ceramic, textile, bone and wood can be utilized as secondary raw materials $[15,16]$.

\section{Methods}

Research is conducted by the accumulation of wastage generated in the process of preparation and service of all the food prepared for the patients, attendants and staff in a state hospital with 618 bed capacity in Eskisehir, through the 20 workdays of 2015 January. Data is recorded as "solid wastes produced" and "solid wastes collected" throughout the study. The solid wastes produced are calculated according to the food registries generated on the basis of the menus that are used in the production and service of food. The organic waste and the packaging waste of the service material and the food is weighed separately with digital precision scales. The solid wastes collected on the other hand is recorded by gathering and weighing all the waste produced at the end of consumption in two distinct areas (inside the kitchens, halls and clinics) by staff who trained by the researcher in waste sorting. Then the solid waste categorized according to their kinds and amounts, and registered in daily log sheets are summed up to reach the total amounts. At the end of the research the total weight of solid waste is found and classified.

\section{Results}

The aim of this study is to identify the kinds and amounts of solid wastes produced in a hospital kitchen and to understand the environmental and economic value of this wastage. Table 1 reports the mass of solid waste produced and the percentage of those eligible for collection. Collectable waste is approximately $2 / 3$ of total produced waste.

\begin{tabular}{|l|l|l|}
\hline Kind of Waste & Solid Waste Produced $(\mathbf{k g})$ & $\%$ \\
\hline Collectable & 4948.9 & 68.4 \\
\hline Not collectable & 2289.6 & 31.6 \\
\hline Total & 7238.5 & 100 \\
\hline
\end{tabular}

Table 1: Total amount of waste produced during the study according to their eligibility for collection, in weight $(\mathrm{kg})$ and percentage (\%). ${ }^{\star}$ Toothpicks and their wrappings, tea bags, cling film, cooked egg shells etc.,

In Table 2, total amounts of produced and collected wastes according to their kinds; the discrepancy in between the amounts produced and collected and the amount and percentage of loss is reported. It has been detected that the total amount of waste produced is 7 tons and $238.5 \mathrm{~kg} .41 .6 \%$ of the total mass of waste is organic (raw), $15.6 \%$ is paper-cardboard, $12.5 \%$ is porcelain, $7.0 \%$ is composite, $3.8 \%$ is metal, $2.3 \%$ is glass and $1.8 \%$ is wood. Whereas the total amount of waste collected is detected to be 4 tons and $422.3 \mathrm{~kg}$; and $66.6 \%$ of this is organic (raw and cooked), $7.3 \%$ is plastic, $7.2 \%$ is paper-cardboard,
9.7\% is porcelain, $1.9 \%$ is composite, $4.6 \%$ is metal, $1.9 \%$ is glass and $0.8 \%$ is wood. $70.7 \%$ of plastic waste, $24.5 \%$ of metal waste, $71.9 \%$ of paper-cardboard waste $83.5 \%$ of composite waste and $74.7 \%$ of organic waste could not be recollected.

\begin{tabular}{|c|c|c|c|c|c|c|}
\hline \multirow[t]{2}{*}{ Kind of Waste } & \multicolumn{2}{|c|}{$\begin{array}{l}\text { Amount of } \\
\text { Solid Waste } \\
\text { Produced }\end{array}$} & \multicolumn{2}{|c|}{$\begin{array}{l}\text { Amount of } \\
\text { Solid } \\
\text { Waste } \\
\text { Collected }\end{array}$} & \multirow{2}{*}{$\begin{array}{l}\text { Amou } \\
\text { nt of } \\
\text { Solid } \\
\text { Waste } \\
\text { Lost } \\
\text { kg }\end{array}$} & \multirow{2}{*}{$\begin{array}{l}\text { The } \\
\text { Discrepan } \\
\text { cy (The } \\
\text { Loss) } \\
\%\end{array}$} \\
\hline & kg & $\%$ & kg & $\%$ & & \\
\hline Plastic & 1106.2 & $\begin{array}{l}15 . \\
3\end{array}$ & 323.8 & 7.3 & 782.4 & 70.7 \\
\hline Metal & 272 & 3.8 & 205.4 & 4.6 & 66.6 & 24.5 \\
\hline Paper-Cardboard & 1132.8 & 15. & 318.5 & 7.2 & 814.3 & 71.9 \\
\hline Composite & 509.4 & 7 & 83.8 & 1.9 & 425.6 & 83.5 \\
\hline Wood & 132 & 1.8 & 36.3 & 0.8 & 95.7 & 72.5 \\
\hline Glass & 165.1 & 2.3 & 83.5 & 1.9 & 81.6 & 49.4 \\
\hline Porcelain & 907.4 & $\begin{array}{l}12 . \\
5\end{array}$ & 427.4 & 9.7 & 480 & 52.9 \\
\hline $\begin{array}{l}\text { Organic waste (raw } \\
\text { food) }\end{array}$ & 2036 & $\begin{array}{l}28 . \\
1\end{array}$ & 516 & $\begin{array}{l}11 . \\
6\end{array}$ & 1520 & 74.7 \\
\hline Organic waste (bone) & 977.8 & $\begin{array}{l}13 . \\
5\end{array}$ & 632 & $\begin{array}{l}14 . \\
2\end{array}$ & 345.8 & 35.4 \\
\hline $\begin{array}{l}\text { Organic waste (cooked } \\
\text { food) }\end{array}$ & - & - & $\begin{array}{l}1795 . \\
7\end{array}$ & $\begin{array}{l}40 . \\
6\end{array}$ & - & - \\
\hline
\end{tabular}

Table 2: The total weights ( $\mathrm{kg}$ ) and percentages (\%) of produced and collected solid wastes during the study; solid waste loss amount $(\mathrm{kg})$ and solid waste loss percentage (\%).

Table 3 shows the economic value calculations for the solid wastes acquired via unit prices received from the subcontractor company which collects the recycling/recovery wastes in Eskisehir's Tepebasi country where the study has been conducted. These financial values have been acquired through the amounts of solid wastes (for example: Amount of plastic waste produced 1106,2 $\mathrm{kg}$ x $0.75 \mathrm{TL}=829,6 \mathrm{TL}$ ). It has been detected that while the total amount of solid waste professed financial value of $829,6 \mathrm{TL}, 586,7 \mathrm{TL}$ is lost due to the amount of waste uncollected. As it is seen in the table, while 1431,8 TL could have been earned from the total amount of solid waste, net profit is 525,4 TL. Moreover, the highest unit price of the recyclable wastes belongs to plastic wastes $(0.75 \mathrm{TL} / \mathrm{kg})$. Unit price of recyclable metal waste is 0.5 TL and the amount earned from the production is $136,0 \mathrm{TL}$. The only profit earned from organic wastes has been acquired through bone waste, which is $95 \mathrm{TL}$.

\begin{tabular}{|l|l|l|l|l|l|l|l|l|}
\hline \multirow{2}{*}{ Kind of waste } & Unit Cost & \multicolumn{2}{|l|}{ Solid Waste Produced } & \multicolumn{2}{l|}{ Solid Waste Collected } & \multicolumn{2}{l|}{ Solid Waste Lost } & \multicolumn{2}{l|}{ Net Profit } \\
\cline { 2 - 10 } & $\mathbf{S L}$ & TL & $\mathbf{\$}$ & TL & $\mathbf{\$}$ & TL & $\mathbf{\$}$ & (TL) \\
\hline Plastic & 0.75 & 829.6 & 306.1 & 242.9 & 89.6 & 586.7 & 216.5 & 242.9 \\
\hline Metal & 0.5 & 136.0 & 50.2 & 102.7 & 37.9 & 33.3 & 12.3 & 102.7 \\
\hline
\end{tabular}


Citation: Yuksel A, Ercan A (2017) Solid Wastes Produced in a Turkish State Hospital Kitchen. Adv Recycling Waste Manag 2: 126. doi: 10.4172/2475-7675.1000126

Page 3 of 5

\begin{tabular}{|l|l|l|l|l|l|l|l|l|}
\hline Paper-Cardboard & 0.25 & 283.2 & 104.5 & 79.6 & 29.4 & 203.6 & 75.1 & 79.6 \\
\hline Wood & 0.15 & 19.8 & 7.3 & 5.4 & 2 & 14.4 & 5.3 & 5.4 \\
\hline Glass & 0.1 & 16.5 & 6.1 & 0 & 0 & 16.5 & 6.1 & 0 \\
\hline Bone & 0.15 & 146.7 & 54.1 & 94.8 & 35 & 51.9 & 19.1 & 94.8 \\
\hline Total & 1431.8 & 528.3 & 525.4 & 193.9 & 906.4 & 334.4 & 525.4 \\
\hline *1 dollar = 2.71 TL Central bank midday/18 June 2015 & & & \\
\hline
\end{tabular}

Table 3: Economic value of solid wastes recycled/recovered (TL/\$).

As it can be observed in Table 4, in order to produce 1 ton $(1000 \mathrm{~kg})$ paper, 17 mature trees, $55.4 \mathrm{~m}^{3}$ water, $2717.5 \mathrm{kwh}$ electricity and 342.0 $\mathrm{cm}^{3}$ natural gas is required [7]. In Table 4 it has been calculated and shown that through the $1132.8 \mathrm{~kg}$ paper waste produced in this study 16 mature tree, $55.0 \mathrm{~m}^{3}$ water, $2625.3 \mathrm{kwh}$ electricity and $265.1 \mathrm{~cm}^{3}$ natural gas can be economized. Simultaneously, this means that from the $1132.8 \mathrm{~kg}$ of paper waste produced, $944.0 \mathrm{~kg}$ paper can be reproduced. It is also indicated that from the $318.5 \mathrm{~kg}$ cardboard waste collected during this study, 4.5 mature trees, $15.6 \mathrm{~m}^{3}$ water, $738.1 \mathrm{kwh}$ electricity and $74.5 \mathrm{~cm}^{3}$ natural gas can be economized.

\begin{tabular}{|c|c|c|c|c|c|}
\hline & \multirow{2}{*}{ Source } & \multirow{2}{*}{ Raw Material ${ }^{1}$} & \multirow{2}{*}{$\mathrm{Su}\left(\mathrm{m}^{3}\right)$} & \multirow{2}{*}{ Electricity (kwh) } & Fuel (natural gas) \\
\hline & & & & & (sm³/ton) \\
\hline \multirow{6}{*}{$\begin{array}{l}\text { Utilization of paper-cardboard } \\
\text { waste in terms of raw material, } \\
\text { water, electricity and fuel }\end{array}$} & \multirow{2}{*}{$\begin{array}{l}\text { Amount necessary for } \\
\text { producing } 1 \text { ton of paper }\end{array}$} & 17 mature tree & \multirow{2}{*}{55.4} & \multirow{2}{*}{2717.5} & \multirow{2}{*}{342} \\
\hline & & ( $2.4 \mathrm{~m} 3$ wood) & & & \\
\hline & \multirow{2}{*}{$\begin{array}{l}\text { Amount necessary for } \\
\text { producing } 1 \text { ton of paper }\end{array}$} & 1.2 ton waste & \multirow{2}{*}{6.5} & \multirow{2}{*}{400} & \multirow{2}{*}{108} \\
\hline & & paper-cardboard & & & \\
\hline & \multirow{2}{*}{$\begin{array}{l}\text { Amount economized by } \\
\text { producing } 1 \text { ton of paper } \\
\text { utilizing paper waste }\end{array}$} & 17 mature tree & \multirow{2}{*}{49.1} & \multirow{2}{*}{2317.5} & \multirow{2}{*}{234} \\
\hline & & $(2.4 \mathrm{~m} 3$ wood $)$ & & & \\
\hline \multirow{6}{*}{$\begin{array}{l}\text { Utilization of paper-cardboard } \\
\text { waste produced and collected at } \\
\text { the end of research in terms of } \\
\text { raw material, water, electricity } \\
\text { and fuel }\end{array}$} & \multirow{2}{*}{$\begin{array}{l}\text { Possible savings generated by } \\
\text { the utilization of } 1132.8 \mathrm{~kg} \\
\text { paper-cardboard waste } \\
\text { produced during the study }\end{array}$} & 16 mature tree & \multirow[b]{2}{*}{55.6} & \multirow[b]{2}{*}{2625.3} & \multirow[b]{2}{*}{265.1} \\
\hline & & (2.3m3 wood) & & & \\
\hline & \multirow{2}{*}{$\begin{array}{l}\text { Savings that will be generated } \\
\text { by the utilization of } 318.5 \mathrm{~kg} \\
\text { paper-cardboard waste } \\
\text { collected during the study }\end{array}$} & 4.5 mature tree & \multirow[b]{2}{*}{15.6} & \multirow[b]{2}{*}{738.1} & \multirow[b]{2}{*}{74.5} \\
\hline & & (0.6m3 wood) & & & \\
\hline & \multirow{2}{*}{$\begin{array}{l}\text { Savings lost due to the } \\
\text { uncollected (lost) } 814.3 \mathrm{~kg} \\
\text { paper-cardboard waste }\end{array}$} & 11.5 mature tree & \multirow{2}{*}{40} & \multirow{2}{*}{1887.2} & \multirow{2}{*}{190.6} \\
\hline & & $\left(1.6 m^{3}\right.$ wood $)$ & & & \\
\hline
\end{tabular}

Table 4: Cost Comparison for Raw Material Usage and Paper Produced with the Collected Waste.

Recovery of plastic wastes, as it can be observed in Table 5 economizes 16 barrels of crude oil and 5.9 kwh electricity per $1000 \mathrm{~kg}$ of plastic waste [6]. From the $1106.2 \mathrm{~kg}$ plastic waste produced in this study, 17.7 barrels of crude oil and $6.5 \mathrm{kwh}$ electricity can be economized. Besides, it has also been found that due to the lost plastic waste, 12.5 barrels of crude oil and 4.6 kwh electricity is wasted.

\begin{tabular}{|c|c|c|c|c|}
\hline $\begin{array}{l}\text { Raw materials and energy } \\
\text { necessary for production }{ }^{1}\end{array}$ & $\begin{array}{l}\text { Savings acquired through } \\
\text { recycling } 1 \text { ton of plastic } \\
\text { waste }\end{array}$ & $\begin{array}{l}\text { Savings acquired with } 1106.2 \mathrm{~kg} \\
\text { plastic waste during this study }\end{array}$ & 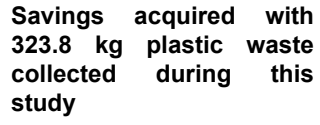 & $\begin{array}{l}\text { Savings lost with the } \\
\text { uncollected } 782.4 \mathrm{~kg} \\
\text { plastic waste }\end{array}$ \\
\hline Crude oil (barrel $\left.{ }^{*}\right)$ & 16 & 17.7 & 5.2 & 12.5 \\
\hline Electricity (kwh) & 5.9 & 6.5 & 1.9 & 4.6 \\
\hline
\end{tabular}

Table 5: Evaluation of the plastic waste produced at the end of the study in terms of raw materials and electricity. ${ }^{*} 1$ barrel=159 L. 
The amount of wastes that are recycled and that could have been recycled during the 20 workdays in the kitchen of this hospital with 618 beds in which the study has been conducted is given at Table 6 . The total amounts of recovered/recycled solid wastes are $6331.1 \mathrm{~kg}$ and utilization percentage of this amount is $25.3 \%$. $3317.3 \mathrm{~kg}$ of these wastes are packaging waste and the utilization percentage is $29.2 \%$. Compost-material wastes are $3013.8 \mathrm{~kg}$ and $21.0 \%$ of this amount is utilized.

\begin{tabular}{|l|l|l|l|}
\hline $\begin{array}{l}\text { Wastes that can } \\
\text { be recycled/ } \\
\text { recovered }\end{array}$ & $\begin{array}{l}\text { Amount of } \\
\text { waste } \\
\text { generated }\end{array}$ & Waste utilized \\
\hline & $\mathbf{k g}$ & $\mathbf{K g}$ & $\%$ \\
\hline Packaging waste* & 3317.3 & 967.7 & 29.2 \\
\hline Compost waste** & 3013.8 & 632 & 21 \\
\hline Total amount & 6331.1 & 1599.7 & 25.3 \\
\hline
\end{tabular}

Table 6: Recovery rates of the solid wastes produced and collected in the kitchen. Porcelain waste is not included, ${ }^{* *}$ Cooked food waste is included.

Throughout the twenty workdays in this hospital with 618 beds, the total recyclable waste produced is $6331.1 \mathrm{~kg}$; meaning $0.51 \mathrm{~kg}$ waste per bed is produced per day. Of this amount, $0.27 \mathrm{~kg} / \mathrm{bed} / \mathrm{day}$ is recoverable packaging waste and $0.24 \mathrm{~kg} / \mathrm{bed} / \mathrm{day}$ is recoverable organic waste.

\section{Discussion}

Waste production per person increases everyday due to the changes in dietary habits [5]. Within a sustainable development approach, waste management strategies that transform waste from a threat to human and environmental health into an economic input should be adopted through the globe [16]. Sortation of solid wastes at their production site, their collection and the overall increase in the amount of waste brought to recycling benefits economy and environment. Furthermore, storage of methane $\left(\mathrm{CH}_{4}\right)$ gas which is known to be 21 times more harmful than carbon dioxide $\left(\mathrm{CO}_{2}\right)$ in systematic storage facilities and its transformation into electric energy; and the reduction of greenhouse gas emissions serve significantly to the protection of human and environmental health [18]. This research has been conducted in a state hospital kitchen, which is a public establishment; and it has been observed that organic and packaging wastes are generated amply. In a previous study in a large hotel [17]; solid wastes produced in all the departments were identified and it has been found that wastes generated in the catering departments were glass, papercardboard, plastic, metal, wood and organic. In the same study, it has been indicated that in restaurants, food halls, canteens and cafeterias both large amounts of food and beverage wastes, and wastes generated due to packaging such as boxes, cartoons and cases are produced in large amounts. In our day, packaged products have also increased along with the developed food industry. Products such as glasses of water in disposable bags have become common in food halls and especially in hospitals. Considering that the raw materials for such plastic packages are petroleum, the necessity for recycling would be admitted beyond dispute.

It has been found that in the food production department of this 618-bed capacity hospital, the amount of organic waste is less than the amount of packaging waste. The scantiness of food waste is pleasing considering the insufficiency of food. However, the same situation simultaneously causes the amount of packaging waste to swell. It is considered in this study that the cardinal reason of this situation is the increased usage of packaged frozen vegetables in food production. In this case, the best route is the recollection of packaging wastes. At the same time, it is fairly important to be attentive not to waste consumable produce in the production of non-frozen foods. In European countries 30 to $40 \%$ of the total mass of waste is composed of organic waste, whereas in Mediterranean countries this percentage increases towards $80 \%$ and the more developed countries are; the less amount of organic waste they produce. In Turkey, an average of 26 million tons of domestic waste is produced and it is reported that this amounts to $1 \mathrm{~kg}$ per day, per person [7]. It is calculated that the amount of waste will increase due to population increase and economic affluence, that it will double in 20 years and that in 2030's household waste will exceed 50 million tons [18]. In many reports, examples are given in order to facilitate the comprehension of this amount. For example, in a research conducted by Izmit Waste and Residue Incineration and Recycling Corp., it is calculated that 1 ton of household waste occupies $1 \mathrm{~m}^{3}$ and 26 million tons of garbage would constitute 4000 soccer fields $(65 \times 100 \mathrm{~m})$ if 1 meter in depth [18].

In a study named WRAP (Waste \& Resources Action Program) conducted in United Kingdom; it has been tried to determine the proportion of organic waste in household waste and it has been found that only for the year of 2009 , this amount is 8,3 tons [19]. Similarly, in a study conducted in France it has been found that in the year of 2007, 9713 tons of organic waste has been sent to scrapheap.

In our country, compost production from organic wastes which is used for the enrichment of soil is regarded as the most important method of utilization. Yet in our country as well as other developing countries, organic waste is thrown into garbage without such treatment. The abundance of organic waste especially in catering businesses and their suitability for compost production displays the necessity of the conduct of waste management.

On the basis of waste management comes the prevention of waste production; and then reduction, recycling, recovery or composting [9]. In this study, existing food production process is transformed in order to decrease the amount of eatable organic waste and through preventing consumable food being wasted; organic waste amount is decreased by 150 kgs. Furthermore, it is important to know the amount of waste produced by a catering business in order to prevent waste generation. In this way, both during purchasing and after the preparation of food, waste production can be decreased. Plus, in terms of the waste that is inevitably produced, it will be known beforehand how many tons will be delivered to compost factories, animal farms or stray animals etc. and what kind of transportation will be required [9].

1.3 billion tons, that is to say one third of all the food produced for human consumption in the world, is thrown away [20]. According to a study of the World Bank (WB), this amount is predicted to increase to 2.2 billion tons in 2025. Solid waste generation is expected to more than double in low-income countries and globally it is expected that expenses will rise from 205 billion dollars to 375.5 billion dollars. As of 2004 China has taken over the position of the country that produces the most waste from United States of America (USA); and it is predicted that by 2030 China will produce double the amount of waste USA produces (6.22). The scope of food waste and the losses through the food production chain is not clearly known in Turkey. In the European Union (EU) it is known that on the one hand the population which receives food aid has grown while on the other hand organic 
waste has reached significant levels [21]. 79 million people live below the poverty line in the EU and 16 million of this receives food aid. It is determined that the amount of food thrown to garbage in the EU every year is 89 million tons in total and $179 \mathrm{~kg}$ per person [14]. It is predicted that this amount will reach to 120 million tons in $2020.43 \%$ of food waste is produced by households, whereas the share of food industry in the wastage is $39 \%$; of transportation $5 \%$ and of restaurants etc., $14 \%$ [22]. In the United Kingdom 8.3 million tons of food is wasted [19], 7 million of which generated by households; 4.2 million of which still consumable meaning every week 6 plates of food is thrown away. In Europe within the 7. Environment Project "Food Use for Social Innovation by Optimizing Waste Prevention Strategies (FUSION)", 6000 people were fed in Brussels by volunteers who peeled and cut $750 \mathrm{~kg}$ of oversupply of vegetables. It is estimated that in Switzerland $1.5 \%$ of all tilled land is wasted due to food waste; and in USA that more than $25 \%$ of drinking water and 300 million barrels of oil is wasted the same way [23].

\section{Conclusion}

Nowadays, all branches of industry should meet their energy demands from renewable sources, population increase should to be stalled, natural resource consumption should be decreased to a minimum and efficiency from these resources maximized, and a production system in which the generated waste is reused as raw material should be adopted. It is claimed that through these strategies the amount of waste emitted to the habitat will be decreased and through the activity of nature's self-renewal process environmental problems will be minimized. Simultaneously, for the solution of the paradox of precarious and insufficient food supply on the one hand and food waste on the other, food waste should be decreased and what is nevertheless generated should be recycled efficiently. In this study, through the investigation of the amounts and kinds of the wastes produced in a hospital kitchen that offers collective catering services, and through the research on the damage inflicted on the environment and its economic scope; the necessity to minimize the amount of waste production and the importance of the following recycling process is demonstrated.

\section{References}

1. Cepel N (1992) Nature, environment, ecology and ecological problems of humanity. Golden Books Press, Istanbul, Turkey.

2. Hanay O, Kocer N (2006) Elazig city solid waste recycling potential determination. Firat University Science and Engineering Science Magazine 18: 507-511.
3. Pongracz E (2002) Redefining the concepts of waste and waste management evolving the theory of waste management, Oulu University Press, Oulu, Finland.

4. Keles R, Hamamci C (2005) Environmental policies, Imge Press, Istanbul, Turkey.

5. Lamb G, Fountain L (2010) An Investigation into food waste management.

6. Yilmaz A, Bozkurt Y (2010) Urban solid waste management practices in Turkey and Kutahya solid waste association example. Suleyman Demirel University Journal of Faculty of Economics and Administrative Sciences 15: 11-28.

7. Altuntop E, Bozlu H, Karabıyı E (2014) Gaining domestic wastes economy

8. Dolekoglu C, Gun S, Giray H (2014) Poverty and food spillover.

9. FAO (2013) Toolkit reducing the food wastage footprint.

10. Ekici $O$ (2005) Sustainable agriculture: Protect the world while producing food. Sci and Tech Magazi 530: 61-65.

11. FAO (2014) Food and Agriculture Organization, Building a common vision for sustainable food and agriculture, Roma.

12. Bayazit AH (2009) The role of consumer education in achieving sustainable consumption behavior. AEUFEM 10: 143-151.

13. OECD (2012) Organization for Economic Co-operation and Development, FAO-Food and Agriculture Organization, Achieving sustainable agricultural productivity growth pp: 50 .

14. CEVKO (2014) Environmental Protection and Packaging Waste Recovery and Recycling Trust Foundation in Turkey.

15. Skordilis A (2004) Modelling of integrated solid waste management systems in an island. Resour Conser and Recyc 41: 243.

16. Palabiyik H, Altunbas D, Marin C (2004) Urban solid wastes and management, contemporary approaches to environmental problems: ecological, economic, political and managerial perspectives. Beta Press, Istanbul, Turkey.

17. Ozgen I (2005) Waste management in large scale hotel enterprises and Iberotel Sarigerme Park example, Dokuz Eylul University, Izmir, Turkey.

18. Ozkan A (2008) The use of different decision making techniques in the construction of urban solid waste management systems, Anadolu University, Eskisehir, Turkey.

19. WRAP (2012) The Waste and Resources Action Program, Household food and drink waste in The United Kingdom, Final Report.

20. FAO (2013) Food and Agriculture Organization, Food waste harms climate, water, land and biodiversity-new FAO report.

21. EESC (2014) European Economic and Social Committee, Prevention and reduction of food waste.

22. EESC (2013) European Economic and Social Committee, Prevention and reduction of food waste, $\mathrm{Pp}: 11$.

23. Buzby JC, Hyman J (2012) Total and per-capita value of food loss in the United States. Food Policy 37: 561-570. 